\title{
How and Why Do Gestational Trophoblastic Neoplasms Overproduce Human Chorionic Gonadotropin?
}

\author{
C. V. Rao \\ Departments of Cellular Biology and Pharmacology, Molecular and Human Genetics and Obstetrics and \\ Gynecology, Reproduction and Development Program, Herbert Wertheim College of Medicine, Florida \\ International University, Miami, USA \\ Email: crao@fiu.edu
}

Received 10 September 2014; revised 18 October 2014; accepted 30 October 2014

Copyright (C) 2015 by author and Scientific Research Publishing Inc.

This work is licensed under the Creative Commons Attribution International License (CC BY). http://creativecommons.org/licenses/by/4.0/

(c) (i) Open Access

\section{Abstract}

From the published data, the present mini-review attempts to answer two fundamental questions about the gestational trophoblastic neoplasms. In addition, it extrapolates the findings to other cancers that produce small amounts of hCG and how a novel therapies could be developed.

\section{Keywords}

\section{Human Chorionic Gonadotropin, hCG Receptors, Gestational Trophoblastic Neoplasms, hCG} Biosynthesis, Choriocarcinoma Cells

\section{Introduction}

Human chorionic gonadotropin (hCG) is a glycoprotein hormone that also belongs to the cystine knot growth factors family [1] [2]. It is a heterodimer of non-covalently bound $\alpha$ and $\beta$ subunits [1]. The alpha subunit is encoded by a single gene, whereas a gene cluster, consisting of six genes, some of which are pseudogenes, encodes the beta subunit [3] [4]. hCG is found in humans as well as in subhuman primates. It is produced in copious amounts by syncytiotrophoblasts in human placenta [5]. In addition, a number of normal tissues and neoplasms can produce small amounts [5]. The non trophoblast derived hCG is not glycosylated, which results in a rapid elimination from circulation [5]. Human placenta derived hCG exists in multiple forms due to differences in glycosylation [6]. These forms as well as free subunits, $\beta$-core fragment, etc. are present in circulation. It is not known, however, whether any of them, except fully (30\% by mass) and hyperglycosylated hCG, are biologically active. None of them, except fully glycosylated hCG, can bind to classical hCG receptors [5]. The distinct 
receptors that others may bind have not been identified.

The hCG receptors are G-protein coupled cell surface receptors [7] [8]. They also bind LH, thus they are also called as hCG/LH receptors. These receptors have been extensively characterized, sequenced, cloned and knockout mouse models have been made [9]. The hCG/LH actions are mediated by the receptors, which for a long time have been thought to be present only in female and male gonads [10]. The published work from around the world has shown that these receptors are also present in many nongonadal tissues [10]. The paradigm shift also suggested that hCG probably has many other functions after the completion of luteo-placental shift in progesterone synthesis at about the $9^{\text {th }}$ week of pregnancy [5].

\section{How Do Gestational Trophoblastic Neoplasms (GTNs) Overproduce hCG}

Very high circulatory hCG levels is a hallmark feature of GTNs [11]. These high levels perhaps reflect both an increased synthesis as well as secretion. These high levels can rarely be seen, if ever, in normal intrauterine pregnancies. Clinicians take advantage of this feature for differential diagnosis of gestational trophoblastic diseases (GTDs) from normal intrauterine pregnancy as well as for determination of the therapeutic response to surgical tumor removal followed by chemotherapy. To the best of our knowledge, no one ever questioned until about 1992 how GTNs can overproduce hCG, when normal placenta cannot [12].

The studies that forced the paradigm shift on the targets of hCG actions have begun to provide the first clues to this enigma. Normal human trophoblasts are some of the newly discovered targets of hCG actions, with syncytiotrophoblasts containing more receptors than cytotrophoblasts [13]. The trophoblast receptors are functional in the self-regulation of hCG biosynthesis [14]. The self-regulation is biphasic, thus lower hCG levels stimulate and higher levels inhibit the synthesis [14]. During this process, hCG downregulates its own receptors [14]. The biphasic self-regulation may explain a rapid early increase of hCG followed by a gradual slow down, reaching a peak, then a fall to about one-tenth peak levels. Once fallen, hCG levels can neither go back up to previous high levels nor fall down to zero, perhaps due to a reset in biphasic self-regulation.

These findings led to studies with hydatidiform moles and choriocarcinomas [12]. To our surprise, these neoplasms not only contained hCG/LH receptors, but their levels are higher than those in normal human placenta. The higher receptor levels suggested that hCG may not be self-regulating its biosynthesis in GTNs. Since it is not possible to test this possibility with neoplasms, immortalized choriocarcinoma cells, which also secrete high hCG levels as GTNs, were used [15]. The cells also contained higher receptor levels, and indeed as predicted, hCG could not influence its synthesis [15]. In the absence of such a regulation, especially negative feedback, hCG can keep on increasing unabated until perhaps a new higher threshold levels are reached. This threshold may vary, which can explain peak level variations seen among patients with GTNs. To date, it is not known what might be the molecular defect in the receptors that selectively impairs its function in the self-regulation of hCG biosynthesis, without affecting the other functions of receptors. This should be extremely interesting line of research.

\section{Why Do GTNs Overproduce hCG}

Based on the belief that GTNs will not expend so much energy in producing huge amounts of hCG that they will not use, we suspected that there might be an insidious reason for the overproduction. If this were to be the case, inhibition of hCG biosynthesis will have consequences to choriocarcinoma cells. To test this possibility, hCG synthesis was inhibited by stable transfection with antisense of gonadotropin— $\alpha$ subunit cDNA [16]. The antisense $\alpha$-subunit transcripts made will dimerize with protein coding sense $\alpha$-subunit transcripts and the dimers formed will then be rapidly degraded by nucleases. As a result, cells can neither make $\alpha$-subunit nor dimer hCG protein.

The choriocarcinoma cells with an inhibited hCG biosynthesis showed an increased apoptosis, DNA fragmentation and decreased invasion across Matrigel membranes, indicating that hCG is a survival factor that also can promote the cells invasion [17]. In athymic immunodeficient nude mice, these cell's showed a dramatically reduced ability to from tumors as compared with native choriocarcinoma cells [17]. This is a clear demonstration of the hCG need for the formation of tumors, their growth, survival and invasion in the host body. Similar results were obtained when hCG synthesis was inhibited by an antisense hCG- $\beta$ subunit DNA transfection or when hCG was neutralized by its specific antibody [18] [19].

The other features of GTDs, such as excessive bleeding, soft uterus, predominance of mononuclear cells and 
hyperemesis, can now be explained by the findings of paradigm shift. Uterine arteries contain hCG receptors and they are involved in vasodialation and angiogenesis [13] [20]-[22]. Thus, hCG produced by GTNs can contribute to excessive bleeding. Human myometrium contains hCG receptors and they play a role in uterine relaxation, which can explain soft uterus [13] [23] [24]. Normal cytotrophoblasthCG receptors play a central role in their differentiation into syncytiotrophoblasts [25] [26]. Dysfunctional tumor trophoblast receptors fail to induce this differentiation, which can explain predominant mononuclear cell phenotype in GTNs. Since syncytiotrophoblasts are the major producers of hCG in normal placenta, this function may have been delegated to cytotrophoblasts in GTNs. Finally, hCG receptors in area postrema of brain, which contains the centers of nausea and vomiting reflexes, are probably hyperactivated by excessive hCG levels to cause frequent and severe episodes of nausea and vomiting [27]. hCG receptors in circulatory and tissue cells of immune system may suppress tumor rejection mechanisms as it does with fetus [28]-[30].

\section{Relevance to Other Neoplasms}

Many other neoplasms such as bladder, testicular, lung, etc. can produce small amounts of non-glycosylated hCG [31]. However, the blood levels in most of these cases barely reach detection limits of the assays. The neoplasms may also contain hCG receptors. Therefore, hCG produced primarily serve as an autocrine factor. It is likely then, as in GTNs, hCG may serve to stimulate tumor growth, development and invasion in the host body. This possibility is exemplified in a studies which showed that an inhibition of hCG synthesis or antibody blocking resulted in a dramatic reduction in the ability of human lung cancer cells to form tumors [32] [33].

\section{Therapeutic Implications}

If hCG is a driver of tumorigenesis, then an inhibition of its synthesis and/or its actions could work as a therapy. In fact, it does as shown in cell cultures and nude mice models. This approach has not yet been tried in patients due to a lack of tumor cell targeted therapies. But this limitation can be overcome by the advances in drug targeting technologies. When that happens, it will be a better alternative to currently used radiation and chemotherapies.

\section{References}

[1] Pierce, J.G. and Parsons, T.F. (1981) Glycoprotein Hormones: Structure and Function. Annual Review of Biochemistry, 50, 465-495. http://dx.doi.org/10.1146/annurev.bi.50.070181.002341

[2] Lapthorn, A.J., Harris, D.C., Littlejohn, A., Lustbader, J.W., Canfield, R.E., Machin, K.J., Morgan, F.J. and Isaacs, N.W. (1994) Crystal Structure of Human Chorionic Gonadotropin. Nature, 369, 455-461. http://dx.doi.org/10.1038/369455a0

[3] Fiddes, J.C. and Goodman, H.M. (1981) The Gene Encoding the Common Alpha Subunit of the Four Human Glycoprotein Hormones. Journal of Molecular and Applied Genetics, 1, 3-18.

[4] Policastro, P., Ovitt, C.E., Hoshina, M., Fukuoka, H., Botthby, M.E. and Boime, I. (1983) The Beta Subunit of Human Chorionic Gonadotropin Is Encoded by Multiple Genes. Journal of Biological Chemistry, 258, 11492-11499.

[5] Lei, Z.M. and Rao, C.V. (2001) Endocrinology of the Trophoblast Tissue. In: Becker, K., Ed., Principles and Practice of Endocrinology and Metabolism, 3rd Edition, Lippincott Williams \& Wilkins, Philadelphia, Chapter 112, 1096-1102,

[6] Cole, L.A., Kardana, A., Andrade-Gordon, P., Gawinowicz, M.A., Morris, J.C., Bergert, E.R., O’Connor, J. and Birken, S. (1991) The Heterogeneity of Human Chorionic Gonadotropin (hCG). III. The Occurrence, Biological and Immunological Activities of Nicked hCG. Endocrinology, 129, 1559-1567. http://dx.doi.org/10.1210/endo-129-3-1559

[7] Loosfelt, H., Misrahi, M., Atger, M., Salesse, R., Vu, M.T., Thi, H.L., Jolivet, A., Guiochon-Mantell, A., Sar, S., Jallal, B., Garnier, J. and Milgrom, E. (1989) Cloning and Sequencing of porcine LH-hCG Receptor cDNA: Variants Lacking Transmembrane Domain. Science, 245, 525-528. http://dx.doi.org/10.1126/science.2502844

[8] McFarland, K.C., Sprengel, R., Phillips, H.S., Kohler, M., Rosembilt, N., Nikolics, N., Segaloff, D.L. and Seeburg, P.H. (1989) Lutropin-Choriogonadotropin Receptor: An Unusual Member of the G Protein-Coupled Receptor Family. Science, 245, 494-499. http://dx.doi.org/10.1126/science.2502842

[9] Lei, Z.M., Mishra, S., Zou, W., Xu, B., Foltz, M., Li, X. and Rao, C.V. (2001) Targeted Disruption of Luteinizing Hormone/Human Chorionic Gonadotropin Receptor Gene. Molecular Endocrinology, 15, 184-200. http://dx.doi.org/10.1210/mend.15.1.0586

[10] Rao, C.V. (2001) Nongonadal Actions of LH and hCG in Reproductive Biology and Medicine. Seminars in Reproductive Medicine, 19, 1-119. 
[11] Zarate, A. and MacGregor, C. (1982) Beta-Subunit hCG and the Control of Trophoblastic Disease. In: Martimbeau, P.W. and Surwit, E.A., Eds., Gestational Trophoblastic Disease. Seminars in Oncology, 1X:2, 187-190.

[12] Lei, Z.M., Rao, C.V., Ackerman, D.M. and Day, T.G. (1992) The Expression of Human Chorionic Gonadotropin/Human Luteinizing Hormone Receptors in Human Gestational Trophoblastic Neoplasms. The Journal of Clinical Endocrinology and Metabolism, 74, 1236-1241.

[13] Reshef, E., Lei, Z.M., Rao, C.V., Pridham, D.D., Chegini, N. and Luborsky, J.L. (1990) The Presence of Gonadotropin Receptors in Nonpregnant Human Uterus, Human Placenta, Fetal Membranes and Decidua. The Journal of Clinical Endocrinology and Metabolism, 70, 421-430. http://dx.doi.org/10.1210/jcem-70-2-421

[14] Licht, P., Cao, H., Lei, Z.M., Rao, C.V. and Merz, W.M. (1993) Novel Self-Regulation of Human Chorionic Gonadotropin Biosynthesis in Term Pregnancy Human Placenta. Endocrinology, 133, 3014-3025.

[15] Licht, P., Cao, H., Zuo, J., Lei, Z.M., Rao, C.V., Merz, W.M. and Day Jr., T.G. (1994) Lack of Self-Regulation of Human Chorionic Gonadotropin Biosynthesis in Human Choriocarcinoma Cells. The Journal of Clinical Endocrinology and Metabolism, 78, 1188-1194.

[16] Cao, H., Lei, Z.M. and Rao, C.V. (1995) Consequences of Antisense Human Chorionic Gonadotropin- $\alpha$ Subunit cDNA Expression in Human Choriocarcinoma JAR Cells. Journal of Molecular Endocrinology, 14, 337-347. http://dx.doi.org/10.1677/jme.0.0140337

[17] Lei, Z.M., Taylor, D.D., Gercel-Taylor, C. and Rao, C.V. (1999) Human Chorionic Gonadotropin Promotes Tumorigenesis of Choriocarcinoma JAR Cells. Placenta, 13, 147-159. http://dx.doi.org/10.1016/S0143-4004(99)80012-5

[18] Hamada, A.L., Nakabayashi, K., Sato, A., Kiyoshi, K., Takamatsu, Y., Laoag-Fernandez, J.B., Ohara, N. and Maruo, T. (2005) Transfection of Antisense Chorionic Gonadotropin BETA Gene into Choriocarcinoma Suppress the Cell Proliferation and Induce Apoptosis. The Journal of Clinical Endocrinology and Metabolism, 90, 4873-4879. http://dx.doi.org/10.1210/jc.2004-2458

[19] Cole, L.A., Khanlian, S.A., Riley, J.M. and Butler, S.A. (2006) Hyperglycosylated hCG in Gestational Implantation and in Choriocarcinoma and Testicular Germ Cell Malignancy Tumorigenesis. The Journal of Reproductive Medicine, 51, 919-929.

[20] Lei, Z.M., Reshef, E. and Rao, C.V. (1992) The Expression of Human Chorionic Gonadotropin/Luteinizing Hormone Receptors in Human Endometrial and Myometrial Blood Vessels. The Journal of Clinical Endocrinology and Metabolism, 75, 651- 659.

[21] Toth, P., Li, X., Rao, C.V., Lincoln, S.R., Sanfilippo, J.S., Spinnato, J.A. and Yussman, M.A. (1994) Expression of Functional Human Chorionic Gonadotropin/Human Luteinizing Hormone Receptor Gene in Human Uterine Arteries. The Journal of Clinical Endocrinology and Metabolism, 79, 307-315.

[22] Zygmunt, M., Herr, F., Keller-Schoenwetter, S., Kunzi-Rapp, K., Munstedt, K., Rao, C.V., Lang, U. and Preissner, K.T. (2002) Characterization of Human Chorionic Gonadotropin as a Novel Angiogenic Factor. The Journal of Clinical Endocrinology and Metabolism, 87, 5290-5296. http://dx.doi.org/10.1210/jc.2002-020642

[23] Ambrus, G. and Rao, C.V (1994) Novel Regulation of Pregnant Human Myometrial Smooth Muscle Cell Gap Junctions by Human Chorionic Gonadotropin, Endocrinology, 135, 2772-2779.

[24] Eta, E., Ambrus, G. and Rao, C.V. (1994) Direct Regulation of Human Myometrial Contractions by Human Chorionic Gonadotropin. The Journal of Clinical Endocrinology and Metabolism, 79, 1582-1586.

[25] Shi, Q.J., Lei, Z.M., Rao, C.V. and Lin, J. (1993) Novel Role of Human Chorionic Gonadotropin in Differentiation of Human Cytotrophoblasts. Endocrinology, 132, 1387-1395.

[26] Yang, M., Lei, Z.M. and Rao, C.V. (2003) The Central Role of Human Chorionic Gonadotropin in the Formation of Human Placental Syncytium. Endocrinology, 144, 1108-1120. http://dx.doi.org/10.1210/en.2002-220922

[27] Lei, Z.M., Rao, C.V., Kornyei, J.L., Licht, P. and Hiatt, E.S. (1993) Novel Expression of Human Chorionic Gonadotropin/Luteinizing Hormone Receptor Gene in Brain. Endocrinology, 132, 2262-2270.

[28] Lin, J., Lojun, S., Lei, Z.M., Wu, W.X., Peiper, S.C. and Rao, C.V. (1995) Lymphocytes from Pregnant Women Express Human Chorionic Gonadotropin/Luteinizing Hormone Receptor Gene. Molecular and Cellular Endocrinology, 111, 13-17. http://dx.doi.org/10.1016/0303-7207(95)03565-O

[29] Zhang, Y.M., Rao, C.V. and Lei, Z.M. (2003) Macrophages in Human Reproductive Tissues Contain Luteinizing Hormone/Chorionic Gonadotropin Receptors. American Journal of Reproductive Immunology, 49, 93-100. http://dx.doi.org/10.1034/j.1600-0897.2003.00013.x

[30] Lei, Z.M., Yang, M., Li, X., Takikawa, O. and Rao, C.V. (2007) Upregulation of Placental Indoleamine 2,3-Dioxygenase by Human Chorionic Gonadotropin. Biology of Reproduction, 76, 639-644. http://dx.doi.org/10.1095/biolreprod.106.056960

[31] Acevedo, H.F., Krichevsky, A., Campbell-Acevedo, E.A., Galyon, J.C., Buffo, M.J. and Hartsock, R.J. (1992) Expres- 
sion of Membrane-Associated Human Chorionic Gonadotropin, Its Subunits, and Fragments by Cultured Human Cancer Cells. Cancer, 69, 1829-1842.

http://dx.doi.org/10.1002/1097-0142(19920401)69:7<1829::AID-CNCR2820690727>3.0.CO;2-0

[32] Kumar, S., Talwar, G.P. and Biswas, D.K. (1992) Necrosis and Inhibition of Growth of Human Lung Tumor by AntiAlpha Human Chorionic Gonadotropin Antibody. Journal of the National Cancer Institute, 84, 42-47. http://dx.doi.org/10.1093/jnci/84.1.42

[33] Rivera, R.T., Pasion, S.G., Wong, D.T.W., Fei, Y. and Biswas, D.K. (1989) Loss of Tumorigenic Potential by Human Lung Tumor Cells in the Presence of Antisense RNA Specific to the Ectopically Synthesized Alpha Subunit of Human Chorionic Gonadotropin. Journal of Cell Biology, 108, 2423-2434. http://dx.doi.org/10.1083/jcb.108.6.2423 
Scientific Research Publishing (SCIRP) is one of the largest Open Access journal publishers. It is currently publishing more than 200 open access, online, peer-reviewed journals covering a wide range of academic disciplines. SCIRP serves the worldwide academic communities and contributes to the progress and application of science with its publication.

Other selected journals from SCIRP are listed as below. Submit your manuscript to us via either submit@scirp.org or Online Submission Portal.
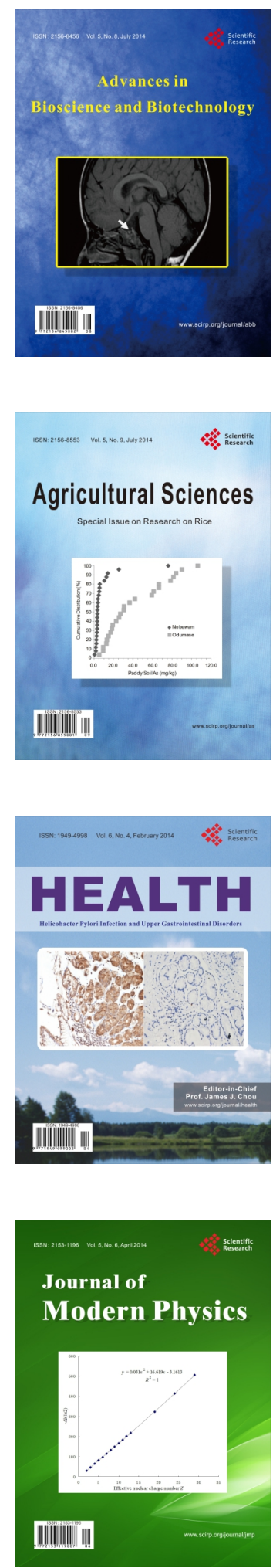
